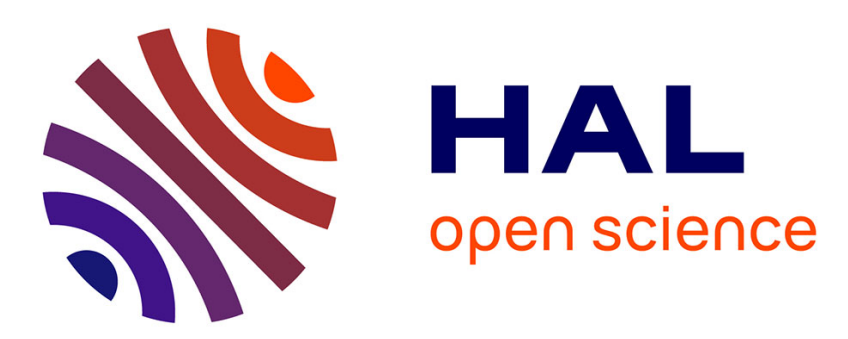

\title{
Climate concerned but anti-nuclear: Exploring (dis)approval of nuclear energy in four European countries
}

Marco Sonnberger, Michael Ruddat, Annika Arnold, Dirk Scheer, Wouter Poortinga, Gisela Böhm, Raquel Bertoldo, Claire Mays, Nicholas Pidgeon, Marc Poumadère, et al.

\section{To cite this version:}

Marco Sonnberger, Michael Ruddat, Annika Arnold, Dirk Scheer, Wouter Poortinga, et al.. Climate concerned but anti-nuclear: Exploring (dis)approval of nuclear energy in four European countries. Energy Research \& Social Science, 2021, 75, pp.102008. 10.1016/j.erss.2021.102008 . hal-03182744

\author{
HAL Id: hal-03182744 \\ https://hal.science/hal-03182744
}

Submitted on 26 Mar 2021

HAL is a multi-disciplinary open access archive for the deposit and dissemination of scientific research documents, whether they are published or not. The documents may come from teaching and research institutions in France or abroad, or from public or private research centers.
L'archive ouverte pluridisciplinaire HAL, est destinée au dépôt et à la diffusion de documents scientifiques de niveau recherche, publiés ou non, émanant des établissements d'enseignement et de recherche français ou étrangers, des laboratoires publics ou privés. 


\section{Climate concerned but anti-nuclear: Exploring (dis)approval of nuclear energy in four European countries}

Marco Sonnberger ${ }^{\mathrm{a}}$, Michael Ruddat ${ }^{\mathrm{a}}$, Annika Arnold ${ }^{\mathrm{a}}$, Dirk Scheer ${ }^{\mathrm{b}}$, Wouter Poortinga ${ }^{\mathrm{c}, \mathrm{d}}$, Gisela Böhm ${ }^{\mathrm{e}, \mathrm{f}}$, Raquel Bertoldo ${ }^{\mathrm{g}}$, Claire Mays ${ }^{\mathrm{h}}$, Nicholas Pidgeon ${ }^{\mathrm{c}}$, Marc Poumadère ${ }^{\mathrm{h}}$, Katharine Steentjes ${ }^{\mathrm{c}}$, Endre Tvinnereim ${ }^{\mathrm{i}, \mathrm{j}}$

${ }^{a}$ University of Stuttgart - Center for Interdisciplinary Risk and Innovation Studies (ZIRIUS)

${ }^{b}$ Karlsruhe Institute of Technology - Institute for Technology Assessment and Systems Analysis (ITAS)

${ }^{c}$ Cardiff University - Understanding Risk Research Group, School of Psychology

${ }^{d}$ Cardiff University - Welsh School of Architecture

${ }^{e}$ University of Bergen - Department of Psychosocial Science, Faculty of Psychology

${ }^{f}$ Inland Norway University of Applied Sciences - Department of Psychology

${ }^{g}$ Aix-Marseille Univ-Laboratoire de Psychologie Sociale

${ }^{h}$ Institut Symlog

${ }^{i}$ University of Bergen - Department of Administration and Organization

${ }^{j}$ NORCE Norwegian Research Centre AS

\section{Corresponding Author:}

Dr. Marco Sonnberger

University of Stuttgart

ZIRIUS - Center for Interdisciplinary Risk and Innovation Studies

Seidenstr. 36

70174 Stuttgart

GERMANY

Phone: $++49+711$ 685-84297

Fax: $++49+711685-84541$

E-mail: marco.sonnberger@ zirius.uni-stuttgart.de 


\begin{abstract}
Energy systems across the world must undergo a fundamental transformation towards the use of low-carbon energy sources and technologies in order to reduce global $\mathrm{CO}_{2}$ emissions. While nuclear energy has historically been highly controversial, especially among people concerned about the environment, some voices have begun to suggest that nuclear energy should be reconsidered as an energy source, to help mitigate climate change.

In this study we explore the relationship between climate change concern and public perceptions of nuclear energy, using representative survey data $(n=4,048)$ from four key energyproducing European countries (France, Germany, Norway, and the United Kingdom). After constructing a climate-change concern index and applying multiple linear regression models, we find that climate change concern is associated with more negative perceptions of nuclear energy in all four countries. These negative associations remain when we control for political orientation, gender, age, and education. Thus, a stable pattern of disapproval of nuclear energy among people concerned about climate change seems to exist independently of national contexts. This result casts into doubt the prospect that broad public support could rapidly emerge for the use (or the increasing use) of nuclear energy as a means to ensure reduced carbon emissions.
\end{abstract}




\section{Introduction}

Nuclear energy has historically been a highly controversial technology, evoking fears and reservations as well as raising high hopes and expectations among stakeholders and the wider public throughout the world. While some people view nuclear energy production as uncontrollable and highly risky, not least as a result of the Chernobyl and Fukushima Daiichi nuclear disasters, others view it as a stable and almost $\mathrm{CO}_{2}$-free source of energy in terms of power-plant operation [1]. This ambiguity also finds expression in environmental movements. Among environmentalists, advocates of nuclear energy see it as a "necessary evil" in the fight against anthropogenic climate change, while others strictly rule it out because of its potential environmental risks, particularly those associated with radioactive waste disposal (see e.g. [2]). While there is already a comprehensive body of country-specific studies on public perceptions of and support for nuclear energy, cross-national comparisons are lacking [3]. Furthermore, as indicated above, the structure of the relationship between public concern about climate change and views on nuclear energy is by no means obvious: either a positive or a negative relationship may be possible. On the one hand, the production of nuclear energy results in close to zero carbon emissions, at least at the point of energy generation, and it could thus in theory be given consideration by anyone favouring robust action on climate change. This reasoning suggests that there should be a positive association between concern about climate change and support for nuclear energy. On the other hand, concern about climate change is often associated with environmentalism, and environmental movements have historically strongly opposed nuclear energy. This argument then leads to the opposing suggestion that there should be a negative association between concern about climate change and support for nuclear energy.

Drawing on survey data collected in June 2016 as part of a cross-European research project, this paper aims to examine the patterns of relationship between climate change concern and public perceptions of nuclear energy in four European countries (France, Germany, Norway, and the United Kingdom [UK]). To our knowledge, this is the first time that such a comparative design has been employed to explore such a relationship; our original research thus falls into the category of "empirically-novel articles" [4, p. 19].

It is particularly worthwhile to compare France, Germany, Norway and the UK, because they represent four key energy-producing nations in Europe with different energy systems, and different histories with respect to nuclear energy [5]. France has since the 1970s relied heavily on nuclear energy, and at the time of our survey in June 2016 was operating 58 reactors at 19 
nuclear power sites spread across the territory. In 2015, the share of nuclear energy in France's total primary energy supply was $46 \%$, and in its total electricity production, $78 \%$ [6]. In the UK, there are currently 15 nuclear power reactors in operation at seven sites distributed across England and Scotland. The share of nuclear energy in the UK's total primary energy supply in 2015 was $10 \%$, and in its total electricity production, $21 \%$ [6]. In 2011, in the wake of the Fukushima Daiichi disaster, Germany decided to phase out its nuclear power plants by the end of 2021. Twenty-nine nuclear reactors in Germany have been permanently shut down, and at the time of the study in 2016 seven reactors were in operation at six sites in the north and south of the country. In 2015, the share of nuclear energy in Germany's total primary energy supply was $8 \%$, and in its total electricity production, $14 \%$ [6]. Finally, nuclear energy has never played a major role in Norway's domestic energy production; three reactors used only for research purposes were operating in June 2016.

A closer look at the different discourses about nuclear energy in the four countries reveals that there have been some remarkable shifts in the last years. Germany initially planned to use nuclear energy as a so-called "bridging technology" in the transition towards a renewable energy system (the so-called "Energiewende") financing renewables and providing security of energy supply $[7,8]$. Thereby, critical voices from politics, environmental organizations and civil society were widely ignored. As mentioned above, this changed dramatically after the Fukushima Daiichi disaster. The reactions in France were in some ways comparable. Although there are no phase out plans for nuclear energy, and an advanced reactor remains under construction, in 2015 the French government decided to reduce France's reliance on nuclear energy to $50 \%$ of the overall electricity mix by 2025 . In the UK, the picture is different. The UK government remains fully committed to nuclear energy, framing it as highly beneficial. Norway, in contrast, is a special case. The country's electricity production is based almost entirely on hydropower. In a normal year, Norway exports electricity to neighbouring countries. The oil and gas industry is a major employer, but plays a subdued role in electricity production, with gas-fired electricity production largely limited to installations on oil and gas platforms in the North Sea. Due to the dominance of hydropower, there are no nuclear plants devoted to energy provision in Norway. Thus, there is no country-specific nuclear energy discourse.

Hence, regarding nuclear energy in particular, these four countries have quite distinct historical and current energy profiles [5], which are also associated with respective policies, public debates, and socio-cultural settings. This makes these four countries valuable cases for comparison. At first glance, the country-specific contexts would suggest the existence of different patterns of nuclear energy perception as well as of different forms of association 
between climate change concern and the perception of nuclear energy across the four countries. However, due to the existence of universal environmental values typically framing nuclear energy as unsustainable, a pattern consistent across the four countries might also be deemed likely.

\section{State of research: climate change concern and public perception of nuclear energy}

\subsection{Public perception of climate change}

Public perception of climate change in the four countries of this study has been extensively investigated since the 1980s [9-12], through both in-depth academic studies [13-15] and continuous polling surveys [16-18]. Public concern about climate change often takes lower priority than other issues of public attention, such as a nation's overall economic situation, unemployment or most recently, migration policies, which people perceive to be more immediate risks and challenges. Scholars attribute this to the psychologically distant character of climate change, asserting that direct personal experience is a crucial factor in people's attention and concern [19-23]. Surveys show that concern about climate change has been increasing over the last two decades globally [24-28] and that knowledge about the causes of climate change has been increasing as well [29]. Outright scepticism regarding climate change appears to be very low across Europe [10,30], even if some fluctuation over time and across countries can be measured [9].

\subsection{Public perception, approval, and (re-)framing of nuclear energy}

Public perceptions of nuclear energy in the UK, Germany, and France are well documented. There is, however, little or no research on the perception of nuclear energy among the public in Norway, which can be attributed to the virtual absence of nuclear power production in that country. For the European Union member states, however, coordinated documentation of public perceptions of nuclear energy dates back to 1982, to one of the first-ever special surveys conducted in the survey series Eurobarometer (no. 17) ${ }^{1}$. This study asked respondents to give their opinion on associated risks and nuclear energy's role in supplying affordable and clean energy [12]. Out of all polled countries, approval ratings for nuclear energy were highest in those countries where nuclear energy was developed on a large scale: a substantial proportion of respondents in the UK, Germany ${ }^{2}$, and France approved of the statement that the

\footnotetext{
${ }^{1}$ This survey polled all member states of the then European Economic Community (EEC).

${ }^{2}$ The survey was limited to the then Federal Republic of Germany, excluding the former German Democratic Republic, as Germany was still a divided state in 1982.
} 
development of nuclear energy is "worthwhile" (France: 51\%; Germany: 37\%; UK: 39\%). In a major USA-France comparative study conducted in 1992 [31], 64\% of French respondents said nuclear energy development was acceptable (although still ranking it last compared with both traditional fossil fuels and renewable sources). Half (51\%) agreed that "in light of health concerns about (...) climate change associated with burning coal and oil, France should rely more heavily on nuclear power to meet future energy needs". However, overall approval ratings for nuclear energy in the EU member states have been decreasing since the 1980s, as data from Eurobarometer 46 show [32]: whereas in 1986, only $7 \%$ of respondents agreed with the statement that nuclear energy poses an unacceptable risk and its usage and development should be abandoned, ten years later, in 1996, 42\% did so. This growing disapproval of nuclear energy throughout Europe can of course be attributed primarily to the consequences of the Chernobyl nuclear disaster in 1986. The decline in approval continued over the years, with $37 \%$ of respondents across all EU member states opposing the use of nuclear energy in their country in the year 2006 [33]. The Fukushima Daiichi nuclear disaster in Japan in March 2011 has led to a further decline in the public's trust in the safety of nuclear power plants, in particular in Japan [34].

However, in the light of climate change and rising global $\mathrm{CO}_{2}$ emissions, some people argue that nuclear energy should be reconsidered [3,35]. Arlt and Wolling [36] point to the release of the Stern Review in the UK in 2006 [37] as one starting point for various political actors and lobbyists to promote nuclear energy as an effective tool in the fight against climate change. After some hesitation, public media have cautiously adopted this narrative [38,39]. In this framing, nuclear energy is presented as an option to ensure stable, affordable, low-carbon energy. If nations want to achieve their $\mathrm{CO}_{2}$ reduction goals, they need to reduce the use of $\mathrm{CO}_{2}$-emitting power production based on natural gas and, notably, coal. Stable and affordable energy supply remain important issues. Following this line of argument, studies have identified a "reluctant acceptance discourse" [40-42]. Marshall [43] points to efforts to reframe nuclear energy as climate friendly and "the real green alternative" to renewable and fossil energy sources alike. Bickerstaff et al. [42] discern an unlikely pro-nuclear coalition of nuclear energy lobbyists and some environmental advocates, two constituencies that traditionally adopt opposing positions with respect to the use and expansion of nuclear energy (see also [44] or [45] for a qualitative study on the discursive struggle in the U.S. American context).

However, while some environmental advocates support the narrative of nuclear energy as a low-carbon, climate-friendly option, at the same time, most of the prominent, powerful environmental advocacy groups and green parties across Europe remain largely opposed, 
presenting nuclear energy as a high-risk technology that compromises public safety $[42,46]$. In this context, studies in the UK have examined empirically the effects on public perception of reframing nuclear energy. Bickerstaff et al. [42] present findings from a mixed-method analysis of public perception of radioactive waste disposal and climate change. Citizen focus groups were, as one part of this study, presented with a climate change frame for nuclear energy. After debating the issue, participants concluded that nuclear energy was not a desirable option, but probably an indispensable component in their country's energy supply in order to deal with climate change. This conditional support sees nuclear energy as the "lesser of two evils" [42, p. 162], while maintaining a general disapproval of the technology. Pidgeon et al. [47] found that while respondents' support for nuclear energy was significantly greater when it was presented as a climate-friendly option, they still preferred alternative options, such as renewables, over nuclear energy. Spence et al. [48] report that higher concern about climate change even decreased the willingness to support nuclear energy as a part of the country's energy mix, although the correlational effects were relatively modest. Wang and Kim [49] offer an explanation for this UK finding by pointing to a negative relationship in a pan-European study between general environmental awareness (environmentalism) and acceptance of nuclear energy $[50,51]$.

\subsection{The social perception of (nuclear energy) risks}

Social science risk research includes multiple theoretical approaches to the social perception of risks. The common ground of these theoretical approaches is the understanding that what people perceive as a risk is always socially constructed. Over the last four decades, theoretical models explaining people's risk perceptions have been developed and tested empirically.

The so-called cultural theory maintains that values or worldviews - that is, ideas of a desirable social order - function as filters for the selection of risks, which are considered by some social groups in society and ignored by others [52-54]. According to the theory, these different social groups (in cultural theory labelled as egalitarians, individualists, hierarchists, and fatalists) hold different values and thus consider different risks as acceptable or inacceptable.

From a more psychological perspective, the psychometric paradigm also focuses on the subjective meanings of risk [55,56], but holds that people subjectively assess risk sources on the basis of various qualitative aspects of risks such as voluntariness of taking the risk, benefits, catastrophic potential of the risk, or personal controllability of the risk. According to the psychometric paradigm, responses to risk are determined by the source's perceived profile on such aspects, with the involuntary, uncontrollable profile perceived as particularly risky, or 
unacceptable.

Another strand of theorizing and empirical research focuses on trust in persons or institutions such as regulatory agencies, government, industry, non-government organizations, and science - as a major factor influencing risk perception and acceptance [57-59]. Here, the main assumption is that trust in persons or organizations that are supposed to regulate the specific risk is a core factor in the acceptance of risks. More specifically, high levels of trust are associated with perceiving high benefits and low risks, and consequently with high acceptance rates [60]. In a similar vein, different general attitudinal constructs such as environmental awareness or cost-benefit perceptions are also used to describe and/or explain risk acceptance [61-63].

The social amplification of risk framework draws attention to the effects of communication about risk events (e.g., nuclear accidents) [64,65]. It is based on the assumption "that risk events interact with psychological, social, and cultural processes in ways that can heighten or attenuate public perceptions of risk and related risk behaviour" [64, p. 178-179]. Risk events are observed and communicated by individuals, groups, and institutions (e.g., mass media) using risk signals (e.g., images or symbols). These risk signals can be processed and interpreted in different ways depending on, for example, cultural biases, values, risk heuristics, or qualitative aspects of risks [65]. The result is either an amplification or an attenuation of the risk event and the risk source.

As this brief overview of the main theoretical approaches in social science risk research has shown, risk has to be understood as a social construct shaped by social and/or psychological factors and processes, in conjunction with specific characteristics of the risk itself. Thus, risks are encoded in interpretative frames that vary across social groups. Empirical research shows too that there are different framings of nuclear energy. These interpretative frames are mainly spread by mass media and have the task of "making sense of relevant events, suggesting what is at issue" [66, p.3]. Examples of such frames that are used for nuclear energy are 'progress' (great potential for energy production), 'energy independence' (being independent from unreliable oil and gas exporting countries), 'runaway' (nuclear energy use has to be abandoned, since humans cannot control it), or 'devil's bargain' (mix of the progress, energy independence, and runaway frames) [7,66]. Part of the 'devil's bargain' frame is also the characterization of nuclear energy as a low carbon energy source ${ }^{3}$ that helps mitigate climate change $[7,40,48,62]$.

\footnotetext{
${ }^{3}$ This characterization is supported by the Fifth Assessment Report of the IPCC: "The literature reviewed [...] shows that the range of technologies can provide electricity with less than $5 \%$ of the lifecycle GHG emissions of coal power: wind, solar, nuclear, and hydropower in suitable locations" [1, p. 540]).
} 


\section{Research scope and research question}

Postulating that the perception of nuclear energy is socially constructed, and that there are different social framings of nuclear energy, amongst which there is a framing as a climate friendly energy source, we derive the research question "how is concern about climate change related to perceptions of nuclear energy". As the review above of the state of research indicates, there is as yet no clear basis on which to predict whether the association between climate change concern and perception of nuclear energy will be positive or negative. Moreover, it is unclear whether the association will be uniform across countries. In the presence of the different framings of nuclear energy, it could well be the case that the association between climate change concern and support for nuclear energy differs across countries or may even be inexistent in some countries.

We have used our own data from France, Germany, Norway, and the UK to explore the research question in four national contexts with very different traditions regarding energy generation in general and nuclear energy in particular. The cross-national comparison of perception patterns should yield valuable insights about the nature of the association between climate change concern and (dis)approval of nuclear energy, since the particular characteristics of countries can be taken into account. The question is whether the same pattern holds for all four countries.

\section{Dataset and methods}

\subsection{The European perceptions of climate change study}

The data for the following analyses came from four nationwide, representative surveys in France, Germany, Norway, and the UK, conducted between June 1st and 17th, 2016, by the international social research company Ipsos MORI. The surveys mainly focused on diverse facets of the public perception of climate change (e.g., relevance of climate change relative to other national issues, images of climate change, concern about climate change, climate change beliefs, psychological distance of climate change, emotions, beliefs about scientific consensus, perception of climate impacts), but also included some few energy-related questions mainly regarding preferences for different energy sources (such as nuclear energy).

The survey questionnaire was developed by the full team of researchers in English and subsequently translated into French, German and Norwegian. A double translation process was applied, with one translation provided by the pertinent national research team and another by professional translators from the employed social research company. Pilot interviews were carried out to test respondents' comprehension of the survey questions, check for translation issues, and assess the reliability of answer scales. 
The French, German and UK surveys ran on a weekly face-to-face omnibus. Interviews were conducted face-to-face at respondents' own homes using Computer-Assisted Personal Interviewing. In each case, the basic population was people aged 15 years and over. The average length of the interviews was around 25 minutes. In each country, stratified random samples were drawn based on country-specific geographical categorisation systems. Depending on the country, quotas were set on age, gender, occupation, rurality, region, town size, employment status, or tenure.

The Norwegian survey was carried out by telephone, as face-to-face interviewing is uncommon in Norway due to the highly dispersed population. The interviews were conducted using Computer Assisted Telephone Interviewing. The average interview length was 24 minutes. The official telephone register was used as the sampling source for the study. The official telephone register includes all private non-anonymised numbers, with $30 \%$ of registered numbers being landline and $70 \%$ being mobile.

The final sample sizes were as follows: The UK sample consisted of 1,033 interviews, the German sample of 1,001 interviews, the French sample of 1,010 interviews, and the Norwegian sample of 1,004 telephone interviews. Each national data set was weighted to ensure that each sample was representative of the respective population. The systematic data collection procedure helped to avoid common pitfalls of quantitative survey research (namely sampling error, coverage error, non-response error, and measurement error [67; 4, p. 24-25]). A comprehensive account of the sampling procedure and survey methodology is provided by Steentjes et al. (2017).

\subsection{Measures}

In order to measure climate change concern, we constructed a climate change concern index using six items ${ }^{4}$. Each of these items was answered on a five-point rating scale. The first item (Q1) refers to the general degree of concern people have about climate change. Related to this item is the question as to whether people feel personally affected by climate change (Q2).

\footnotetext{
${ }^{4}$ The wording of the items in the questionnaire was as follows: Q1: How worried, if at all, are you about climate change?

Q2: Climate change is likely to have a big impact on people like me.

Q3: When you think about climate change and everything that you associate with it, how strongly, if at all, do you feel each of the following emotions? Fear

Q4: When you think about climate change and everything that you associate with it, how strongly, if at all, do you feel each of the following emotions? Outrage

Q5: I am prepared to greatly reduce my energy use to help tackle climate change.

Q6: Some people have moral concerns about climate change. For example, because they think that its harmful impacts are more likely to affect poorer countries, or because they feel a moral responsibility towards future generations. To what extent, if at all, do you have moral concerns about climate change?
} 
Research suggests that feeling personally affected by climate change brings the issue closer to people and increases the likelihood of favouring policies and behaviour to mitigate climate change $[11,15]$. Additionally, emotions have been identified as an influential factor in people's perception of various risks and the related actions they may take [68-73]. Weber points out that stronger negative emotions such as fear (Q3) and outrage (Q4) serve as motivators to "remove ourselves from a dangerous situation or to change the environment in ways that remove us from risk" [72, p. 104]. Respondents were also asked to assess their willingness to contribute personally to climate change mitigation by reducing their personal use of energy (Q5); this item connects assessments of feelings and beliefs to aspects of actual personal behaviour. Moral responsibility in the face of climate change is a dimension that relates to people's understanding of action and consequences (Q6). Climate change is also an issue of environmental justice [74]. Moreover, the degree to which people feel morally responsible for their (personal or societal) behaviour can have real-world impacts [70].

These six items can be assigned to three distinct components used in the measurement of attitudes. Social psychological research differentiates between a cognitive component, an affective component and a conative - that is, behaviour-related - component of attitudes. Cognition refers to thoughts about a certain topic. Affect denotes the subject's positive or negative feelings towards a certain topic. The conative component finally comprises the will to act in a certain manner with respect to the topic, or the actual behaviour with respect to the topic [75-77]. According to these definitions, items Q2 and Q6 can be assigned to the cognitive component. Q1, Q3 and Q4 are connected to the affective component. Q5 shows a link to the conative component.

Table 1 shows results of the factor analysis, which was employed to explore the dimensionality of the selected items included in the climate change concern index.

\section{Table 1}

Factor loadings and communalities based on a principal component analysis.

\begin{tabular}{lcc} 
Item & Communalities & Loadings factor 1 \\
\hline Q1: Concern about climate change & .611 & .782 \\
Q2: Personally affected by climate change & .364 & .603 \\
Q3: Emotion towards climate change: Fear & .559 & .747 \\
Q4: Emotion towards climate change: Outrage & .497 & .705 \\
Q5: Personal energy use & .372 & .610 \\
Q6: Moral concerns about climate change & .492 & .702 \\
\hline
\end{tabular}


Note: $\mathrm{n}=3.720$; extraction method: principal component; no rotation; 1 component extracted, explained variance $=48.3 \%$; Kaiser-Meyer Olkin $=0.823$, Bartlett test of sphericity: $p<0.05$, Cronbach's $\alpha=0.80$.

The factor analysis yielded a one-dimensional solution, which suggests that the selected items all measure the same latent dimension. This is in line with prior research findings concerning the "[...] connection between cognitions, emotions and behaviour [...]" [71, p. 734]. This connection is, among others, theoretically elaborated in the dual-process model of risk evaluation introduced by Böhm and Pfister, which has already been successfully tested empirically $[68,71,78]$. Kaiser Meyer Olkin values above 0.8 demonstrate valid characteristics for the suitability of the sample [79, p 225] and a significant result of the Bartlett test of sphericity $(\mathrm{p}<0.05)$ indicates the existence of correlations between the variables [80, p. 685686]. The six items were internally consistent (Cronbach's $\alpha=0.80),{ }^{5}$ and together appear to be a sound instrument for measuring climate change concern. The climate change index was constructed by averaging the scores of the six items, meaning that it ranges from 1 as the lowest score (i.e., very low concern about climate change) to 5 as the highest score (i.e., very high concern about climate change).

The perception of nuclear energy was elicited with an item worded as follows: "What is your general opinion about nuclear power as a method of energy generation for the UK/ Germany/ France/ Norway? Please indicate how positive or negative your opinion is". The item was answered with response categories ranging from $1=$ very negative to $5=$ very positive. There is a longstanding discussion of whether Likert items with at least five response categories, such as our nuclear perception variable, can be treated as quasi-interval level data (for pro argumentation, see [82]; for contra argumentation, see [83]). We assume that the categories of our nuclear perception variable are psychologically equidistant in the survey participants' minds, since the response categories are formulated so that they are equally spaced (very negative - mainly negative - neither positive nor negative - mainly positive - very positive). Furthermore, in many studies, parametric statistics have been proven to be robust with respect to violations of their basic assumptions when using Likert items as dependent variables (for a comprehensive overview, see [82]). Thus, we regard the use of statistical procedures requiring interval level data to be justified.

\footnotetext{
${ }^{5}$ Typically, values for Cronbach's $\alpha$ of .7 and above are classified as acceptable [81, p. 231].
} 


\section{Results}

\subsection{Climate change concern in cross-national comparison}

Table 2 shows the means of the climate change concern index for the four countries involved in the study as well as the results of the comparison of group means. Respondents from France are most concerned about climate change, followed by respondents from Germany, Norway and the UK.

Significant differences in the level of climate change concern between the four countries were identified by running an ANOVA with post-hoc tests. Due to variance heterogeneity, the Brown-Forsythe-Test as global test procedure was applied [80, p. 443-444]. The test result (p $<0.01)$ indicated existing significant differences in the level of climate change concern among some of the four countries. A Dunnett-T3 as post-hoc test identified significant differences between the groups $[80$, p. 459]. Norway and the UK score significantly lower $(p<0.05)$ on the climate change concern index than do France and Germany. The French respondents have the highest score on the index in comparison to the other three countries. Only the difference between Norway and the UK is not statistically significant. All in all, with means ranging from 2.90 to 3.34 on the index, which ranges from 1 (very low concern) to 5 (high concern), climate change concern seems to be moderate in the four surveyed countries.

\section{Table 2}

Cross-country comparison of climate change concern.

\begin{tabular}{lccccc}
\multirow{2}{*}{ Country } & $\mathrm{M}(\mathrm{SD})$ & $\mathrm{n}$ & \multicolumn{3}{c}{ Mean difference $(\mathrm{SE})$} \\
\cline { 5 - 6 } & & & France & Germany & Norway \\
\hline France & $3.34(0.76)$ & 972 & & & \\
Germany & $3.08(0.74)$ & 857 & $0.26^{* *}(0.04)$ & & \\
Norway & $2.92(0.81)$ & 913 & $0.42^{* *}(0.04)$ & $0.16^{* *}(0.04)$ & \\
UK & $2.90(0.82)$ & 979 & $0.44^{* *}(0.04)$ & $0.18^{* *}(0.04)$ & $0.02(0.04)$ \\
\hline
\end{tabular}

Note: $\mathrm{M}=$ mean; $\mathrm{SD}=$ standard deviation; $\mathrm{n}=$ number of cases; $\mathrm{SE}=$ standard error; $* \mathrm{p}<0.05, * * \mathrm{p}<0.01$; index ranging from $1=$ no climate change concern to $5=$ high climate change concern .

\subsection{Perception of nuclear energy in cross-national comparison}

Figure 1 gives an overview of the percent distribution in each of the four countries of negative and positive opinion concerning nuclear energy (with the two positive and the two negative endpoints of the 5-point scale pooled for better readability).

Nuclear energy is seen in a mainly negative light in France, Germany and Norway. Respondents 
in the UK were more positive in their opinion towards nuclear energy than their counterparts, with $45 \%$ of respondents indicating a very or mainly positive opinion of nuclear energy, and only $33 \%$ viewing it mainly or very negatively. The view of nuclear energy is especially negative in Norway and Germany. These descriptive findings are in line with previous research on the topic [84].

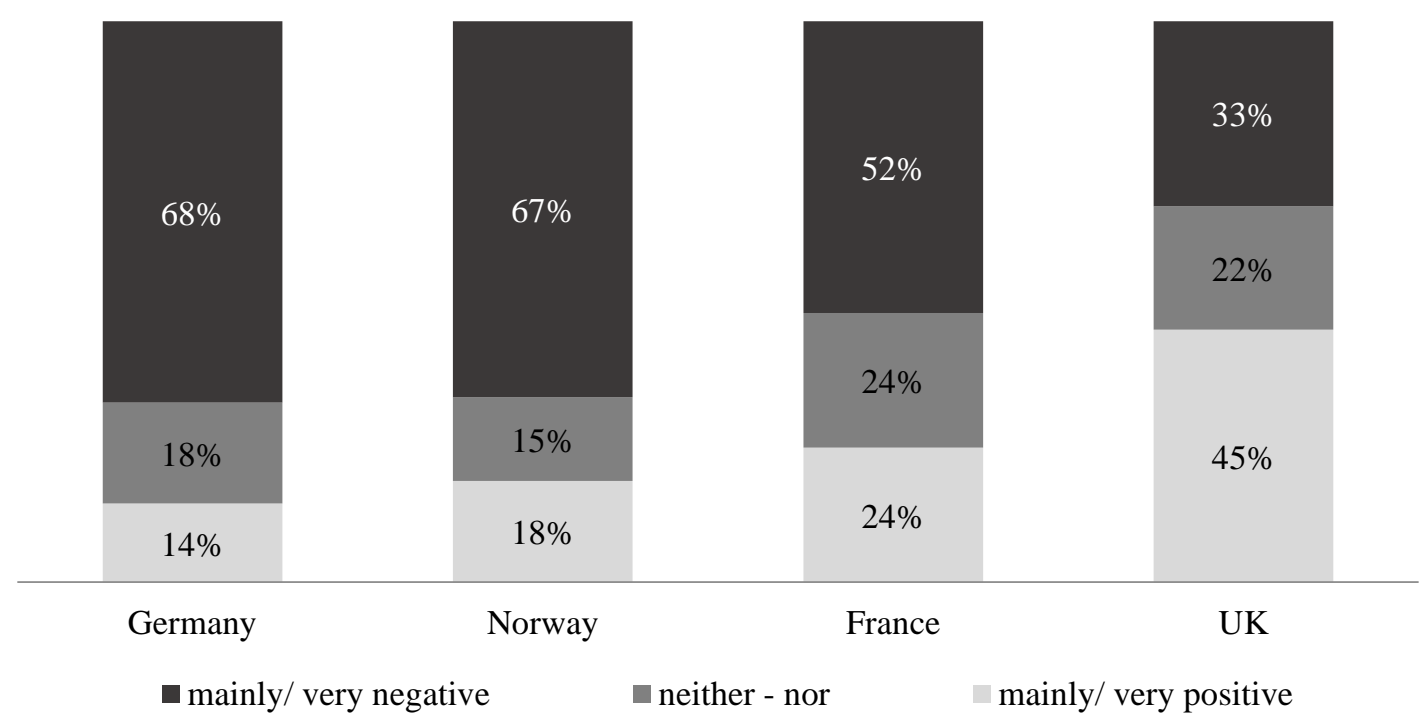

Note: Item wording: "What is your general opinion about nuclear power as a method of energy generation for the UK/ Germany/ France/ Norway? Please indicate how positive or negative your opinion is"; response scale: $1=$ very negative $-5=$ very positive.

Fig. 1. Perceptions of nuclear energy in Germany, Norway, France and the UK.

Table 3 shows the distribution characteristics of the perception of nuclear energy for every country as well as the results of a comparison of group means. Significant differences in the perception of nuclear energy between the four countries were identified by running an ANOVA and post-hoc tests. Table 3 shows that respondents in the UK had significantly more positive perceptions of nuclear energy compared with the other three countries. As shown above, UK respondents were also the least concerned about climate change. German respondents, scoring second highest on the climate change concern index, showed more negative perceptions of nuclear energy in comparison with France and the UK. The difference in perceptions of nuclear energy between Germany and Norway was not significant.

\section{Table 3}

Cross-country comparison of nuclear energy perceptions. 


\begin{tabular}{lccccc} 
& \multirow{2}{*}{ Country } & $\mathrm{M}(\mathrm{SD})$ & $\mathrm{n}$ & \multicolumn{3}{c}{ Mean difference $(\mathrm{SE})$} \\
\cline { 5 - 6 } & & & France & Germany & Norway \\
\hline France & $2.52(1.15)$ & 990 & & & \\
Germany & $2.07(1.13)$ & 973 & $0.45^{* *}(0.05)$ & & \\
Norway & $2.13(1.25)$ & 958 & $0.39^{* *}(0.05)$ & $-0.06 \cdot(0.06)$ & \\
UK & $3.13(1.28)$ & 934 & $-0.61^{* *}(0.06)$ & $-1.06^{* *}(0.05)$ & $-1.00^{* *}(0.06)$ \\
\hline
\end{tabular}

Note: $\mathrm{M}=$ mean; $\mathrm{SD}=$ standard deviation; $\mathrm{SE}=$ standard error; $* \mathrm{p}<0.05, * * \mathrm{p}<0.01$; item wording: "What is your general opinion about nuclear energy as a method of energy generation in [UK/ Germany/ France/ Norway]? Please indicate how positive or negative your opinion is"; response scale: $1=$ very negative $-5=$ very positive.

\subsection{The relation between climate change concern and perceptions of nuclear energy}

In the next step, we analysed the correlations between the climate change concern index and the perception of nuclear energy in each of the four countries. As shown in Figure 2, negative correlations were found between climate change concern and perceptions of nuclear energy in all four countries, although they differed somewhat in size. That is, considering the four countries in alphabetical order, in France $(r=-0.22, p<0.01)$, UK $(r=-0.12, p<0.01)$, Norway $(\mathrm{r}=-0.09, \mathrm{p}<0.05)$ and Germany $(\mathrm{r}=-0.15, \mathrm{p}<0.01)$, respondents who were more concerned about climate change tended to perceive nuclear energy less favourably.

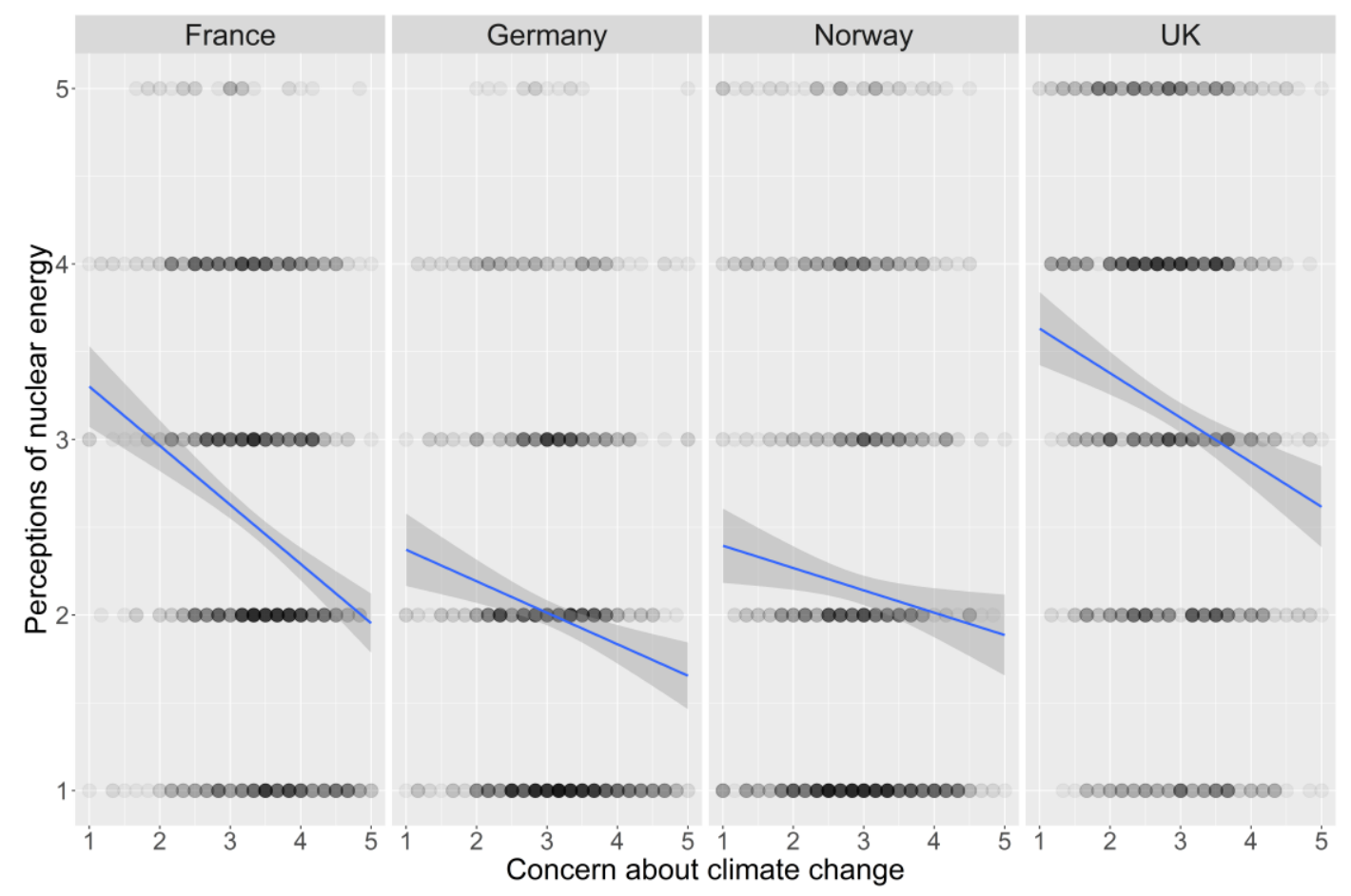

Fig. 2. Association between climate change concern index and perception of nuclear energy in France, Germany, Norway and the UK. 
To test the robustness of the identified negative relationship between climate change concern and nuclear energy perceptions, we ran multiple linear regression analyses for each country as well as for the overall sample including political orientation ${ }^{6}$, gender, education (university degree yes/no), and age (grouped 25-34, 35-44, 45-54, 55-65, and 65+) ${ }^{7}$ as controls. These control variables were derived from the state of research that shows various socio-demographic influences on the support for nuclear energy: women tend to oppose nuclear energy more often than do men [35], leftist or liberal political orientation decreases support for nuclear energy [85-87], and higher education increases support for nuclear energy [88]. Lastly, age has been shown to be positively related to the approval of nuclear energy [49,89]. We introduced the control variables into the regression models in a first step and then added the climate change concern index in a second step. We believe this provides a more detailed picture of the relationship between climate change concern and perception of nuclear energy than would entering all predictors simultaneously.

As already mentioned above, we regard the dependent variable - nuclear energy perception as quasi-interval scaled. Thus, we consider running linear regressions as justified. However, we also ran ordinal regressions as the nonparametric equivalent to linear regression, in order to check the robustness of our results (the results of the ordinal regressions can be found in Table 6 in the Appendix). Table 4 shows the results of the linear regression models. A summary of the characteristics of the variables included in the regression models can be found in Table 5 in the Appendix.

\footnotetext{
${ }^{6}$ The survey question was worded as follows: "In politics people sometimes talk of left and right. Using a scale from 0 to 10 , where would you place yourself on this scale?" (0 representing "left" and 10 "right").

${ }^{7}$ In our data set, the respondents' age was only available as a grouped variable. Thus, we had to include the different age groups as dummy variables into the regression models.
} 
Table 4

Linear regression models predicting perceptions of nuclear energy from climate change concern and various control variables in the UK, France, Germany, and Norway.

\begin{tabular}{|c|c|c|c|c|c|c|c|c|c|c|c|c|c|c|c|c|}
\hline \multirow[b]{2}{*}{ Block } & \multirow[b]{2}{*}{ Variables } & \multicolumn{3}{|c|}{ UK } & \multicolumn{3}{|c|}{ France } & \multicolumn{3}{|c|}{ Germany } & \multicolumn{3}{|c|}{ Norway } & \multicolumn{3}{|c|}{ Overall } \\
\hline & & $\mathbf{B}$ & $\mathbf{S E}$ & $\mathbf{B}$ & $\mathbf{B}$ & SE & B & B & SE & B & B & SE & B & B & SE & B \\
\hline \multirow{11}{*}{1} & Left-right scale & $0.13 * *$ & 0.02 & $0.20 * *$ & $0.05 *$ & 0.02 & $0.10 *$ & $0.08 * *$ & 0.02 & $0.14 * *$ & $0.06 * *$ & 0.02 & $0.12 * *$ & $0.06 * *$ & 0.01 & $0.11 * *$ \\
\hline & Female $^{\mathrm{a}}$ & $-0.66^{* *}$ & 0.08 & $-0.26^{* *}$ & $-0.26^{*}$ & 0.08 & $-0.11 *$ & -0.13 & 0.08 & -0.06 & $-0.45 * *$ & 0.08 & $-0.18 * *$ & $-0.38 * *$ & 0.04 & $-0.15^{* *}$ \\
\hline & University degree ${ }^{b}$ & $0.24 * *$ & 0.09 & $0.09 * *$ & 0.09 & 0.08 & 0.04 & -0.01 & 0.14 & -0.00 & $0.22 *$ & 0.09 & $0.09 *$ & $0.09 *$ & 0.05 & $0.03 *$ \\
\hline & Age $25-34^{c}$ & 0.07 & 0.15 & 0.02 & $0.34 *$ & 0.15 & $0.11 *$ & 0.19 & 0.17 & 0.06 & $-0.37 *$ & 0.16 & $-0.10 *$ & -0.07 & 0.08 & -0.02 \\
\hline & Age $35-44^{c}$ & 0.17 & 0.16 & 0.05 & $0.30 *$ & 0.15 & $0.10 *$ & 0.28 & 0.17 & 0.09 & $-0.61 * *$ & 0.15 & $-0.19 * *$ & -0.13 & 0.08 & -0.04 \\
\hline & Age $45-54^{c}$ & -0.06 & 0.15 & -0.02 & 0.21 & 0.15 & 0.07 & $0.34 *$ & 0.16 & $0.13 *$ & $-0.85^{* *}$ & 0.15 & $-0.27 * *$ & $-0.26 * *$ & 0.08 & $-0.08 * *$ \\
\hline & Age $55-64^{c}$ & 0.06 & 0.16 & 0.02 & $0.57 * *$ & 0.15 & $0.18^{* *}$ & $0.46^{* *}$ & 0.17 & $0.16^{* *}$ & $-0.96 * *$ & 0.16 & $-0.26^{* *}$ & -0.13 & 0.08 & -0.04 \\
\hline & Age $65+^{c}$ & -0.01 & 0.15 & -0.00 & $0.58 * *$ & 0.14 & $0.21 * *$ & $0.39 *$ & 0.16 & $0.15^{*}$ & $-1.00 * *$ & 0.14 & $-0.32 * *$ & $-0.18 *$ & 0.07 & $-0.06 *$ \\
\hline & Adjusted $\mathrm{R}^{2}$ & \multicolumn{3}{|c|}{0.106} & \multicolumn{3}{|c|}{0.043} & \multicolumn{3}{|c|}{0.028} & \multicolumn{3}{|c|}{0.113} & \multicolumn{3}{|c|}{0.037} \\
\hline & F statistics & \multicolumn{3}{|c|}{$13.75 * *$} & \multicolumn{3}{|c|}{$5.61 * *$} & \multicolumn{3}{|c|}{$3.74 * *$} & \multicolumn{3}{|c|}{$14.34 * *$} & \multicolumn{3}{|c|}{$17.78 * *$} \\
\hline & $\mathrm{n}$ & \multicolumn{3}{|c|}{884} & \multicolumn{3}{|c|}{848} & \multicolumn{3}{|c|}{848} & \multicolumn{3}{|c|}{913} & \multicolumn{3}{|c|}{3493} \\
\hline \multirow{18}{*}{2} & $\begin{array}{l}\text { Climate change } \\
\text { concern (CCC) }\end{array}$ & $-0.14 * *$ & 0.05 & $-0.09 * *$ & $-0.31 * *$ & 0.05 & $-0.20 * *$ & $-0.15 * *$ & 0.05 & $-0.10 * *$ & $-0.14 *$ & 0.06 & $-0.09 *$ & $-0.26 * *$ & 0.05 & $-0.17 * *$ \\
\hline & Left-right scale & $0.12 * *$ & 0.02 & $0.18 * *$ & $0.03 *$ & 0.02 & $0.07 *$ & $0.08 * *$ & 0.02 & $0.13 * *$ & $0.04 *$ & 0.02 & $0.09 *$ & $0.06 * *$ & 0.01 & $0.11 * *$ \\
\hline & Female $^{\mathrm{a}}$ & $-0.62 * *$ & 0.08 & $-0.24 * *$ & $-0.17 *$ & 0.08 & $-0.07 *$ & -0.09 & 0.08 & -0.04 & $-0.39 * *$ & 0.08 & $-0.16^{* *}$ & $-0.34 * *$ & 0.04 & $-0.13 * *$ \\
\hline & University degree ${ }^{b}$ & $0.27 * *$ & 0.09 & $0.10 * *$ & 0.12 & 0.08 & 0.05 & -0.01 & 0.14 & -0.00 & $0.24 * *$ & 0.09 & $0.10 * *$ & $0.12 * *$ & 0.05 & $0.05^{* *}$ \\
\hline & Age $25-34^{c}$ & 0.05 & 0.15 & 0.02 & $0.43 * *$ & 0.15 & $0.13 * *$ & 0.23 & 0.17 & 0.07 & $-0.41 * *$ & 0.16 & $-0.12 * *$ & 0.04 & 0.08 & 0.01 \\
\hline & Age $35-44^{c}$ & 0.17 & 0.16 & 0.05 & $0.38 * *$ & 0.14 & $0.13 * *$ & 0.30 & 0.17 & 0.10 & $-0.65 * *$ & 0.15 & $-0.20 * *$ & 0.02 & 0.08 & 0.01 \\
\hline & Age $45-54^{c}$ & -0.06 & 0.15 & -0.02 & 0.28 & 0.14 & 0.09 & $0.37 *$ & 0.16 & $0.14 *$ & $-0.91 * *$ & 0.15 & $-0.28 * *$ & -0.11 & 0.08 & -0.03 \\
\hline & Age $55-64^{c}$ & 0.06 & 0.16 & 0.02 & $0.65 * *$ & 0.15 & $0.20 * *$ & $0.50 * *$ & 0.16 & $0.17 * *$ & $-1.02 * *$ & 0.16 & $-0.28 * *$ & 0.01 & 0.08 & 0.00 \\
\hline & Age $65+^{c}$ & -0.05 & 0.15 & -0.01 & $0.63 * *$ & 0.14 & $0.23 * *$ & $0.40 *$ & 0.16 & $0.15^{*}$ & $-1.07 * *$ & 0.15 & $-0.34 * *$ & -0.06 & 0.07 & -0.02 \\
\hline & $\mathrm{UK}^{\mathrm{d}}$ & --- & --- & --- & --- & --- & --- & --- & --- & --- & --- & --- & --- & 0.27 & 0.23 & 0.09 \\
\hline & Germany $^{\mathrm{d}}$ & --- & --- & --- & --- & --- & --- & --- & --- & --- & --- & --- & --- & $-0.95 * *$ & 0.26 & $-0.31 * *$ \\
\hline & Norway $^{\mathrm{d}}$ & --- & --- & --- & --- & --- & --- & --- & --- & --- & --- & --- & --- & $-1.19 * *$ & 0.24 & $-0.41 * *$ \\
\hline & CCC $x$ UK $^{\mathrm{e}}$ & --- & --- & --- & --- & --- & --- & --- & --- & --- & --- & --- & --- & 0.08 & 0.07 & 0.09 \\
\hline & CCC x Germany ${ }^{\mathrm{e}}$ & --- & --- & --- & --- & --- & --- & --- & --- & --- & --- & --- & --- & 0.14 & 0.08 & 0.15 \\
\hline & CCC x Norway ${ }^{e}$ & --- & --- & --- & --- & --- & --- & --- & --- & --- & --- & --- & --- & $0.22 * *$ & 0.07 & $0.23 * *$ \\
\hline & Adjusted $\mathrm{R}^{2}$ & & 0.112 & & & 0.081 & & & 0.037 & & & 0.118 & & & 0.166 & \\
\hline & F statistics & & $13.07 * *$ & & & $9.03 * *$ & & & $4.23 * *$ & & & $13.51 * *$ & & & $44.53 * *$ & \\
\hline & $\mathrm{n}$ & & 862 & & & 824 & & & 760 & & & 841 & & & 3287 & \\
\hline
\end{tabular}

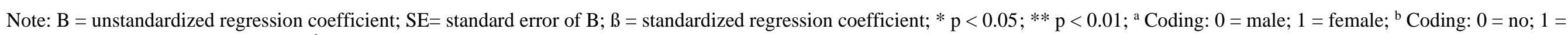

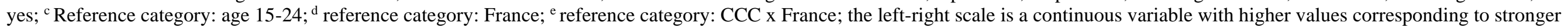
right-wing orientation $(1=$ left; 11 = right $)$ 
When we checked the least square assumptions, we found no indication of serious violations of the assumption of normal distribution of residuals, or of the linearity assumption. We also found no indication of multi-collinearity or heteroscedasticity [90, p. 125-140]. Thus, the respective theoretical assumptions of linear regression analysis are fulfilled in each of the regression models. Furthermore, the ordinal regression models (see Table 6 in the Appendix) - with only minor deviations concerning the significance of some control variables - yield the same results. The relevant results of the linear regression models therefore can be regarded as robust.

Each of the four national models in Table 4 shows a significant negative relationship of climate change concern to the perception of nuclear energy. Thus, in each of the four countries, higher levels of climate change concern imply more negative perceptions of nuclear energy. That is, there is a uniform association between climate change concern and perceptions of nuclear energy, which is independent of the four surveyed national backgrounds. However, as revealed by the stepwise introduction of the control variables and the climate change concern index into the regression models, the contribution of the climate change concern index to the overall explained variance varies from country to country. While in the case of France the adjusted $\mathrm{R}^{2}$ value nearly doubles with the introduction of the climate change concern index into the regression model (block 1: adjusted $\mathrm{R}^{2}=0.043$; block 2: adjusted $\mathrm{R}^{2}=0.081$ ) and in the case of Germany it rises substantially (block 1: adjusted $\mathrm{R}^{2}=0.028$; block 2: adjusted $\mathrm{R}^{2}=0.037$ ), the contribution of the climate change concern index to the overall explained variance is small in the cases of $\mathrm{UK}$ and Norway ( $\mathrm{UK}$ - block 1: adjusted $\mathrm{R}^{2}=0.106$; block 2: adjusted $\mathrm{R}^{2}=$ 0.112 / Norway - block 1: adjusted $\mathrm{R}^{2}=0.113$; block 2: adjusted $\mathrm{R}^{2}=0.118$ ). Overall, the four regression models show relatively low adjusted $\mathrm{R}^{2}$ values (France: 0.081, Germany: 0.037, Norway: 0.118, UK: 0.112).

The negative association between perceptions of nuclear energy and climate change concern is largest in France $(\mathrm{B}=-0.31)$; the other three models show somewhat smaller associations (between $\mathrm{B}=-0.14$ and $\mathrm{B}=-0.15$ ). Some associations between the control variables and perception of nuclear energy are statistically significant in the different countries. Political orientation is significantly and positively related to perception of nuclear energy in all four countries, meaning that the further to the right a respondent places themself on the political spectrum, the more positive is their perception of nuclear energy. Furthermore, women are less positively oriented towards nuclear energy than men, with the exception of Germany, where no gender effect is observed. Having a university degree is related to a more positive perception of nuclear energy in the UK and Norway. In the UK, there are no significant differences between the different age groups. In France, groups of higher age - except for ages 45-54 - 
tend to regard nuclear energy more positively than the reference group (age 15-24), while in Norway the opposite is the case. In Germany, it is only the age groups 45-54, 55-64, and 65+ that consider nuclear energy to be more acceptable than does the reference group. All in all, compared with the strength of the associations between the significant control variables and the dependent variable, the (negative) association between climate change concern and people's views on nuclear energy is more moderate in three of the four countries, with France's more highly negative association being the exception.

We subsequently ran a multiple regression model on the total sample, to which we added the countries as dummy variables and interactions of climate change concern with these dummy variables (see right hand column, Table 4). The model was constructed to test whether the associations of climate change concern with perceptions of nuclear energy are different in the four countries. France, where the (negative) association was the strongest, was chosen as the reference country. Table 4 shows that, when controlling for the other variables, perceptions of nuclear energy are more negative in Germany $(B=-0.95)$ and Norway $(B=-1.19)$ than in France. The positive climate change concern $x$ Norway interaction $(B=0.22)$ shows there is a weaker negative association of climate change concern with perceptions of nuclear energy in Norway than in France. No significant differences were found in the strength of association between France on the one hand and the UK and Germany on the other. The right-hand column of Table 4 further shows that across the four countries climate change concern, gender, and political orientation are the most important factors in the perception of nuclear energy, followed by the possession of a university degree. No significant differences were found between the different age groups.

\section{Discussion and conclusion}

Our analyses have shown a significant negative association between climate change concern and the public perception of nuclear energy in each of the four surveyed countries (high climate change concern is associated with a negative opinion of nuclear energy). Our results show that this negative association is independent of the national context where it is observed (at least in the four surveyed countries). However, the strength of the relationship varies with national contexts. The results yield several interesting insights and provide suggestions for further research, which we will now reflect upon and discuss against the current state of knowledge.

First, levels of climate change concern and valence of opinion on nuclear energy as an energy source are shown to differ significantly across the four countries. The largest differences are found in the perceptions of nuclear energy: the most positive views of nuclear energy are held 
in the UK, followed at some distance by France, Norway, and Germany. Somewhat less pronounced differences were found in climate change concern: it is highest in France, followed by Germany, Norway, and the UK. We may surmise that these differing levels are embedded within and differentiated by a country's social, political, and cultural heritage [5,31].

Second, despite their exhibited differences, the four countries nonetheless show an overall similarity in the pattern of relationship between climate change concern and the approval of nuclear energy. Our findings are in line with the findings of previous quantitative studies identifying an inverse relationship between climate change concern and nuclear energy perceptions among the public [48-51]. Thus, the hypothesis that high climate change concern is associated with negative perceptions of nuclear energy has once again found support. We were able to show that such an inverse relationship exists in four major energy-producing European countries, despite their diversity with respect to their absolute levels of approval of nuclear energy as measured by our survey, and also with respect to the structure of the national energy systems, including the actual and historic extent of nuclear energy use. Our study revealed that nuclear energy is not an unanimously preferred option for mitigating climate change through energy systems: across the four countries, people who are concerned about climate change do not see nuclear energy as a solution. Thus, the negative association between climate change concern and the perception of nuclear energy seems to be independent of national contexts, although the strength of that relationship varies across countries. Here the pattern is differentially shaped by various measured features (gender, political orientation, education). Because the inverse relationship is observed in these four different countries of Northern and Western Europe, it can be hypothesized that it may also exist in other modern, industrialised Western countries; further studies like ours can investigate the particular weight of background features in each context.

Third, our results suggest there may be little likelihood of a successful reframing of nuclear energy as a measure in reducing global $\mathrm{CO}_{2}$ emissions. Public support for nuclear energy seems to be very limited. Furthermore, there is no indication in our results that the narrative of expanding the use of nuclear energy to combat climate change will resonate with those members of the public who are concerned about climate change. The 'climate friendliness of nuclear' narrative (or 'devil's bargain' frame, which would hypothetically show high climate concern to contribute to high approval for nuclear energy) does not appear to be greatly influential and effective in the contexts we studied, nor is it the only frame that exists. The older narrative of 'nuclear as a threat due to its high catastrophic potential' (or 'runaway' frame), which dates to the beginning of the anti-nuclear movement in the early 1970s, seems to retain the upper hand. 
Signs that the 'runaway' frame is weakening are apparent only in the case of Norway, where the younger generation displays more positive perceptions of nuclear energy than do older cohorts. All in all, efforts to reframe perceptions of nuclear energy may not be in keeping with the current landscape of public opinions towards this energy source and thus may be unlikely to gain broad public support. Our findings do not necessarily exclude the possibility of a nuclear renaissance from a public acceptance perspective, but they do seriously question the potential of using climate friendliness as a frame for recruiting nuclear energy supporters among persons concerned by climate change. However, an alternative view might be that reframing nuclear energy in terms of climate friendliness could become more persuasive in the light of the prominent 'climate emergency' discourses now beginning to emerge, and considering the declarations being made in so many countries around the globe (see e.g. [91]). Furthermore, since the collective and individual experience of climate change impacts may become more pressing - and a significant decrease in electricity consumption is unlikely to be popular - reframing efforts may become more successful.

Fourth, the climate change concern index developed in this study expands existing approaches to measuring climate change concern by including and detailing further relevant facets of concern. The climate change concern index presented by McCright [92] consists of three items, including perception that the seriousness of global warming is underestimated in the news, as well as worry about global warming and perception that global warming will threaten one's personal way of life. Our index of six items reflects the latter two components (general concern, expectation of personal consequences) and adds to this basis by including emotions (fear and outrage), behavioural intentions, and moral responsibility. In this way our climate change concern index offers richer and broader coverage of factors influencing lay people's climate change concerns.

Finally, we recognize a weakness in our results due to a restriction in our data collection. The explained variance was relatively low in all four regression models. This corresponds to the fact that, besides the control variables, only one predictor variable (climate change concern) could be included in the models. Our survey mandate was centred on climate change perceptions and the questionnaire could not carry sufficient items to support a multifaceted analysis of nuclear energy perception or, therefore, a comprehensive theoretical model of risk perception to be tested by regression. The regression models may remain underspecified. Other studies have examined nuclear energy perception with a much broader range of predictor variables (e.g., $[40,93])$. Rather than trying to maximize the amount of explained variance in the perception of nuclear energy by introducing a grand variety of existing questionnaire items, we chose to focus 
explicitly on the nature of the relationship between climate change concern and approval of nuclear energy across the four surveyed countries with their distinct energy profiles and nuclear energy discourses. However, the climate change concern index is only one little piece in explaining nuclear energy perception. Thus, cross-national examinations of nuclear energy perception drawing on a broader range of potentially relevant predictor variables (see section 2.3) would be a worthwhile endeavour, in order to confirm (or not) our results.

\section{Acknowledgements}

This work was supported by the Joint Programme Initiative on Climate Change (JPI), a research programme uniting National Research Councils across Europe. Our "European Perceptions of Climate Change" study, under the leadership of Professor Nick Pidgeon, was co-funded by the UK Economic and Social Research Council (grant number: ES/M009505/1), France's Agence Nationale de la Recherche (grant number: ANR-14-JCLI-0003), the KLIMAFORSK programme of the Norwegian Research Council (grant number: 244904), a cooperation agreement between Equinor (formerly Statoil) and the University of Bergen (Akademiaavtale; project number: 803589) and the German Federal Ministry of Education and Research (grant number: 01UV1403).

\section{References}

[1] Bruckner T, Bashmakov IA, Mulugetta Y, Chum H, de la Vega Navarro, A., Edmonds J et al. Energy Systems. In: IPCC, editor. Climate Change 2014: Mitigation of Climate Change. Contribution of Working Group III to the Fifth Assessment Report of the Intergovernmental Panel on Climate Change. Cambridge, New York: Cambridge University Press; 2014, p. 511-598.

[2] McCalman C, Connelly S. Destabilizing Environmentalism: Epiphanal Change and the Emergence of Pro-Nuclear Environmentalism. Journal of Environmental Policy \& Planning 2019;21(5):549-62. https://doi.org/10.1080/1523908X.2015.1119675.

[3] Pampel FC. Support for Nuclear Energy in the Context of Climate Change. Organization \& Environment 2011;24(3):249-68. https://doi.org/10.1177/1086026611422261.

[4] Sovacool BK, Axsen J, Sorrell S. Promoting novelty, rigor, and style in energy social science: Towards codes of practice for appropriate methods and research design. Energy Research \& Social Science 2018;45(6357):12-42. https://doi.org/10.1016/j.erss.2018.07.007.

[5] Arnold A, Böhm G, Corner A, Mays C, Pidgeon NF, Poortinga W et al. European Perceptions of Climate Change. Socio-political profiles to inform a cross-national survey in France, Germany, Norway and the UK. Oxford: Climate Outreach; 2016.

[6] International Energy Agency. CO2 Emissions from fuel combustion. Highlights. Paris; 2015.

[7] Butler C, Parkhill KA, Pidgeon NF. Nuclear Power After Japan: The Social Dimensions. Environment: Science and Policy for Sustainable Development 2011;53(6):3-14. https://doi.org/10.1080/00139157.2011.623051. 
[8] BMWi, BMU. Energiekonzept für eine umweltschonende, zuverlässige und bezahlbare Energieversorgung. Berlin; 2010.

[9] Capstick S, Whitmarsh L, Poortinga W, Pidgeon N, Upham P. International trends in public perceptions of climate change over the past quarter century. Wiley Interdisciplinary Reviews: Climate Change 2015;6(1):35-61. https://doi.org/10.1002/wcc.321.

[10] Engels A. Anthropogenic climate change: How to understand the weak links between scientific evidence, public perception, and low-carbon practices. Energy and Emission Control Technologies 2016;4:17. https://doi.org/10.2147/EECT.S63005.

[11] Wolf J, Moser SC. Individual understandings, perceptions, and engagement with climate change: Insights from in-depth studies across the world. Wiley Interdisciplinary Reviews: Climate Change 2011;2(4):547-69. https://doi.org/10.1002/wcc.120.

[12] Riffault H, Tchernia J-F. Public Opinion in the European Community: Energy. Brussels; 1982.

[13] Hagen B, Middel A, Pijawka D. European Climate Change Perceptions: Public support for mitigation and adaptation policies. Environmental Policy and Governance 2016;26(3):170-83. https://doi.org/10.1002/eet.1701.

[14] Leiserowitz AA. Global Warming's Six Americas. New Haven, CT; 2009.

[15] Lorenzoni I, Pidgeon NF. Public Views in Climate Change: European and USA Perspectives. Climatic Change 2006;77(1-2):73-95.

[16] TNS Opinion \& Social. Standard Eurobarometer 67. Brussels; 2007.

[17] TNS Opinion \& Social. Standard Eurobarometer 69. Brussels; 2008.

[18] TNS Opinion \& Social. Standard Eurobarometer 81. Brussels; 2014.

[19] Akerlof K, Maibach EW, Fitzgerald D, Cedeno AY, Neuman A. Do people "personally experience" global warming, and if so how, and does it matter? Global Environmental Change 2013;23(1):81-91. https://doi.org/10.1016/j.gloenvcha.2012.07.006.

[20] O’Neill SJ, Hulme M. An iconic approach for representing climate change. Global Environmental Change 2009;19(4):402-10. https://doi.org/10.1016/j.gloenvcha.2009.07.004.

[21] Pidgeon N. Climate change risk perception and communication: addressing a critical moment? Risk Analysis 2012;32(6):951-6. https://doi.org/10.1111/j.15396924.2012.01856.x.

[22] Spence A, Poortinga W, Pidgeon N. The psychological distance of climate change. Risk Analysis 2012;32(6):957-72. https://doi.org/10.1111/j.1539-6924.2011.01695.x.

[23] Tvinnereim E, Lægreid OM, Liu X, Shaw D, Borick C, Lachapelle E. Climate change risk perceptions and the problem of scale: evidence from cross-national survey experiments. Environmental Politics 2020:1-21. https://doi.org/10.1080/09644016.2019.1708538.

[24] Goldberg M, Gustafson A, Rosenthal S, Kotcher J, Maibach E, Leiserowitz AA. For the first time, the Alarmed are now the largest of Global Warming's Six Americas. New Haven, CT: Yale Program on Climate Change Communication; 2020.

[25] Whitmarsh L, Seyfang G, O’Neill S. Public engagement with carbon and climate change: To what extent is the public 'carbon capable'? Global Environmental Change 2011;21(1):56-65. https://doi.org/10.1016/j.gloenvcha.2010.07.011.

[26] Corner A, Demski C, Steentjes K, Pidgeon NF. Engaging the public on climate risks and adaptation: A briefing for UK communicators. Oxford: Climate Outreach; 2020.

[27] The Centre for Climate Change and Social Transformations. Public Opinion in a Time of Climate Emergency; 2019. 
[28] Steentjes K, Demski C, Seabrook A, Corner A, Pidgeon N. British Public Perceptions of Climate Risk, Adaptation Options and Resilience (RESiL RISK): Topline findings of a GB survey conducted in October 2019. Cardiff: Cardiff University; 2020.

[29] Shi J, Visschers VHM, Siegrist M. Public Perception of Climate Change: The Importance of Knowledge and Cultural Worldviews. Risk Analysis 2015;35(12):2183201. https://doi.org/10.1111/risa.12406.

[30] Poortinga W, Whitmarsh L, Steg L, Böhm G, Fisher S. Climate change perceptions and their individual-level determinants: A cross-European analysis. Global Environmental Change 2019;55:25-35. https://doi.org/10.1016/j.gloenvcha.2019.01.007.

[31] Slovic P, Flynn J, Mertz CK, Poumadère M, Mays C. Nuclear Power and the Public. In: Renn O, Rohrmann B, editors. Cross-Cultural Risk Perception. Boston, MA: Springer US; 2000, p. 55-102.

[32] INRA Europe. Eurobarometer 46: European Commission and Energy Matters; 1997.

[33] TNS Opinion \& Social. Special Eurobarometer 262: Energy Technologies: Knowledge, Perception, Measures. Brussels; 2007.

[34] Poortinga W, Aoyagi M, Pidgeon NF. Public perceptions of climate change and energy futures before and after the Fukushima accident: A comparison between Britain and Japan. Energy Policy 2013;62:1204-11. https://doi.org/10.1016/j.enpol.2013.08.015.

[35] Sundström A, McCright AM. Women and nuclear energy: Examining the gender divide in opposition to nuclear power among swedish citizens and politicians. Energy Research \& Social Science 2016;11:29-39. https://doi.org/10.1016/j.erss.2015.08.008.

[36] Arlt D, Wolling J. Fukushima effects in Germany? Changes in media coverage and public opinion on nuclear power. Public understanding of science 2016;25(7):842-57. https://doi.org/10.1177/0963662515589276.

[37] Stern N. The Economics of Climate Change: The Stern Review. Cambridge: Cambridge University Press; 2006.

[38] Doyle J. Acclimatizing nuclear? Climate change, nuclear power and the reframing of risk in the UK news media. International Communication Gazette 2011;73(1-2):107-25. https://doi.org/10.1177/1748048510386744.

[39] Arlt D. Laufzeitverlängerung von Atomkraftwerken - Nein, Danke!?: Eine kommunikationswissenschaftliche Studie zum Einfluss medialer Kommunikation auf Einstellungen gegenüber Atomkraft. Ilmenau: Universitätsverlag Ilmenau; 2013.

[40] Corner A, Venables D, Spence A, Poortinga W, Demski C, Pidgeon N. Nuclear power, climate change and energy security: Exploring British public attitudes. Energy Policy 2011;39(9):4823-33. https://doi.org/10.1016/j.enpol.2011.06.037.

[41] Teräväinen T, Lehtonen M, Martiskainen M. Climate change, energy security, and riskdebating nuclear new build in Finland, France and the UK. Energy Policy 2011;39(6):3434-42. https://doi.org/10.1016/j.enpol.2011.03.041.

[42] Bickerstaff K, Lorenzoni I, Pidgeon NF, Poortinga W, Simmons P. Reframing nuclear power in the UK energy debate: nuclear power, climate change mitigation and radioactive waste. Public understanding of science 2008;17(2):145-69. https://doi.org/10.1177/0963662506066719.

[43] Marshall E. Nuclear power. Is the friendly atom poised for a comeback? Science 2005;309(5738):1168-9. https://doi.org/10.1126/science.309.5738.1168.

[44] Kinsella WJ. Rearticulating Nuclear Power: Energy Activism and Contested Common Sense. Environmental Communication 2015;9(3):346-66.

https://doi.org/10.1080/17524032.2014.978348. 
[45] Greenberg MR. Nuclear waste management, nuclear power and energy choices: Public preferences, perceptions, and trust. London: Springer; 2013.

[46] DeLuca KM. Greenpeace International Media Analyst Reflects on Communicating Climate Change. Environmental Communication 2009;3(2):263-9. https://doi.org/10.1080/17524030902972734.

[47] Pidgeon NF, Lorenzoni I, Poortinga W. Climate change or nuclear power-No thanks!: A quantitative study of public perceptions and risk framing in Britain. Global Environmental Change 2008;18(1):69-85. https://doi.org/10.1016/j.gloenvcha.2007.09.005.

[48] Spence A, Venables D, Pidgeon NF, Poortinga W, Demski C. Public Perceptions of Climate Change and Energy Futures in Britain: Summary Findings of a Survey Conducted in January-March 2010: Technical Report. Cardiff; 2010.

[49] Wang J, Kim S. Comparative Analysis of Public Attitudes toward Nuclear Power Energy across 27 European Countries by Applying the Multilevel Model. Sustainability 2018;10(5):1518. https://doi.org/10.3390/su10051518.

[50] Groot JIM de, Steg L. Morality and nuclear energy: perceptions of risks and benefits, personal norms, and willingness to take action related to nuclear energy. Risk Analysis 2010;30(9):1363-73. https://doi.org/10.1111/j.1539-6924.2010.01419.x.

[51] Vainio A, Paloniemi R, Varho V. Weighing the Risks of Nuclear Energy and Climate Change: Trust in Different Information Sources, Perceived Risks, and Willingness to Pay for Alternatives to Nuclear Power. Risk Analysis 2017;37(3):557-69. https://doi.org/10.1111/risa.12640.

[52] Douglas M, Wildavsky AB. Risk and culture: An essay on the selection of technological and environmental dangers. Berkeley: University of California Press; 1982.

[53] Wildavsky AB, Dake K. Theories of Risk Perception: Who Fears What and Why? Daedalus 1990;119(4):41-60.

[54] Thompson M, Ellis RJ, Wildavsky AB. Cultural theory. Boulder, San Francisco, Oxford: Westview Press; 1990.

[55] Slovic P. Perception of Risk. Science 1987;236(4799):280-5. https://doi.org/10.1126/science.3563507.

[56] Slovic P. Perceptions of Risk: Reflections on the Psychometric Paradigm. In: Krimsky S, Golding D, editors. Social Theories of Risk. Westport: Praeger; 1992, p. 117-152.

[57] Cvetkovich G. The attribution of social trust. In: Cvetkovich G, Löfstedt RE, editors. Social trust and the management of risk. London: Earthscan; 1999, p. 53-61.

[58] Earle TC, Cvetkovich G. Social trust and culture in risk management. In: Cvetkovich G, Löfstedt RE, editors. Social trust and the management of risk. London: Earthscan; 1999, p. 9-21.

[59] Renn O, Levine D. Credibility and trust in risk communication. In: Kasperson RE, Stallen, Pieter Jan M., editors. Communicating risks to the public: International perspectives. Dordrecht: Kluwer Academic Publishers; 1991, p. 175-218.

[60] Siegrist M, Cvetkovich G, Roth C. Salient Value Similarity, Social Trust, and Risk/Benefit Perception. Risk Analysis 2000;20(3):353-62.

[61] Jones CR, Eiser JR. Identifying predictors of attitudes towards local onshore wind development with reference to an English case study. Energy Policy 2009;37(11):460414. https://doi.org/10.1016/j.enpol.2009.06.015.

[62] Perlaviciute G, Steg L. Contextual and psychological factors shaping evaluations and acceptability of energy alternatives: Integrated review and research agenda. Renewable 
and Sustainable Energy Reviews 2014;35:361-81.

https://doi.org/10.1016/j.rser.2014.04.003.

[63] Liebe U, Dobers GM. Decomposing public support for energy policy: What drives acceptance of and intentions to protest against renewable energy expansion in Germany? Energy Research \& Social Science 2019;47:247-60. https://doi.org/10.1016/j.erss.2018.09.004.

[64] Kasperson RE, Renn O, Slovic P, Brown HS, Emel J, Goble R et al. The Social Amplification of Risk: A Conceptual Framework. Risk Analysis 1988;8(2):177-87.

[65] Kasperson JX, Kasperson RE, Pidgeon NF, Slovic P. The social amplification of risk: assessing fifteen years of research and theory. In: Pidgeon NF, Slovic P, Kasperson RE, editors. The social amplification of risk. Cambridge: Cambridge University Press; 2003, p. 13-46.

[66] Gamson WA, Modigliani A. Media Discourse and Public Opinion on Nuclear Power: A Constructionist Approach. American Journal of Sociology 1989;95(1):1-37. https://doi.org/10.1086/229213.

[67] Dillman DA, Smyth JD, Christian LM. Internet, Phone, Mail, and Mixed-Mode Surveys: The Tailored Design Method. 4th ed. Hoboken: Wiley; 2014.

[68] Böhm G. Emotional reactions to environmental risks: Consequentialist versus ethical evaluation. Journal of Environmental Psychology 2003;23(2):199-212. https://doi.org/10.1016/S0272-4944(02)00114-7.

[69] Pfister H-R, Böhm G. The multiplicity of emotions: A framework of emotional functions in decision making. Judgment and Decision Making 2008;3(1):5-17.

[70] Böhm G, Pfister H-R. Emotion und Moral bei der Risikowahrnehmung. Spektrum der Wissenschaft Spezial 2012:66-73.

[71] Böhm G, Pfister H-R. The perceiver's social role and a risk's causal structure as determinants of environmental risk evaluation. Journal of Risk Research 2017;20(6):732-59. https://doi.org/10.1080/13669877.2015.1118148.

[72] Weber EU. Experience-Based and Description-Based Perceptions of Long-Term Risk: Why Global Warming does not Scare us (Yet). Climatic Change 2006;77(1-2):103-20. https://doi.org/10.1007/s10584-006-9060-3.

[73] Demski C, Capstick S, Pidgeon N, Sposato RG, Spence A. Experience of extreme weather affects climate change mitigation and adaptation responses. Climatic Change 2017;140(2):149-64. https://doi.org/10.1007/s10584-016-1837-4.

[74] Routledge P. Translocal Climate Justice Solidarities. In: Dryzek JS, Norgaard RB, Schlosberg D, editors. Oxford handbook of climate change and society. Oxford, U.K., New York: Oxford University Press; 2011, p. 384-398.

[75] Eagly AH, Chaiken S. The Psychology of Attitudes. Belmont: Wadsworth; 1993.

[76] Maloney MP, Ward MP. Ecology: Let's hear from the people: An objective scale for the measurement of ecological attitudes and knowledge. American Psychologist 1973;28(7):583-6. https://doi.org/10.1037/h0034936.

[77] Maloney MP, Ward MP, Braucht GN. A revised scale for the measurement of ecological attitudes and knowledge. American Psychologist 1975;30(7):787-90. https://doi.org/10.1037/h0084394.

[78] Böhm G, Pfister H-R. Action tendencies and characteristics of environmental risks. Acta Psychologica 2000;104(3):317-37. https://doi.org/10.1016/S0001-6918(00)00035-4.

[79] Hutcheson G, Sofroniou N. The Multivariate Social Scientist. London: SAGE; 1999.

[80] Field A. Discovering statistics using IBM SPSS statistics: And sex and drugs and rock 'n' roll. 4th ed. Los Angeles, London, New Delhi, Singapore, Washington DC: SAGE; 2013. 
[81] George D, Mallery P. SPSS for Windows step by step: A simple guide and reference 18.0 update. 11th ed. Boston: Allyn \& Bacon; Pearson; 2011.

[82] Norman G. Likert scales, levels of measurement and the "laws" of statistics. Advances in Health Sciences Education 2010;15(5):625-32. https://doi.org/10.1007/s10459-0109222-y.

[83] Jamieson S. Likert scales: how to (ab)use them. Medical Education 2004;38(12):1217-8. https://doi.org/10.1111/j.1365-2929.2004.02012.x.

[84] Engels A, Hüther O, Schäfer M, Held H. Public climate-change skepticism, energy preferences and political participation. Global Environmental Change 2013;23(5):101827. https://doi.org/10.1016/j.gloenvcha.2013.05.008.

[85] Costa-Font J, Rudisill C, Mossialos E. Attitudes as an expression of knowledge and "political anchoring": the case of nuclear power in the United Kingdom. Risk Analysis 2008;28(5):1273-88. https://doi.org/10.1111/j.1539-6924.2008.01094.x.

[86] Edberg K, Tarasova E. Phasing out or phasing in: Framing the role of nuclear power in the Swedish energy transition. Energy Research \& Social Science 2016;13:170-9. https://doi.org/10.1016/j.erss.2015.12.008.

[87] Latré E, Thijssen P, Perko T. The party politics of nuclear energy: Party cues and public opinion regarding nuclear energy in Belgium. Energy Research \& Social Science 2019;47:192-201. https://doi.org/10.1016/j.erss.2018.09.003.

[88] Nguyen VP, Yim M-S. Examination of different socioeconomic factors that contribute to the public acceptance of nuclear energy. Nuclear Engineering and Technology 2018;50(5):767-72. https://doi.org/10.1016/j.net.2018.02.005.

[89] Nuclear Energy Agency. Public Attitudes to Nuclear Power. Paris: OECD Publishing; 2010.

[90] Cohen J, Cohen P, West SG. Applied multiple regression/correlation analysis for the behavioral sciences. 3rd ed. Mahwah, NJ: Erlbaum; 2010.

[91] Ripple WJ, Wolf C, Newsome TM, Barnard P, Moomaw WR. Corrigendum: World Scientists' Warning of a Climate Emergency. BioScience 2020;70(1):8-12. https://doi.org/10.1093/biosci/biz152.

[92] McCright AM. The effects of gender on climate change knowledge and concern in the American public. Population and Environment 2010;32(1):66-87. https://doi.org/10.1007/s11111-010-0113-1.

[93] Peters E, Slovic P. The Role of Affect and Worldviews as Orienting Dispositions in the Perception and Acceptance of Nuclear Power. Journal of Applied Social Psychology 1996;26(16):1427-53. https://doi.org/10.1111/j.1559-1816.1996.tb00079.x. 


\section{Appendix}

\section{Table 5}

Summary of variables included in the regression models.

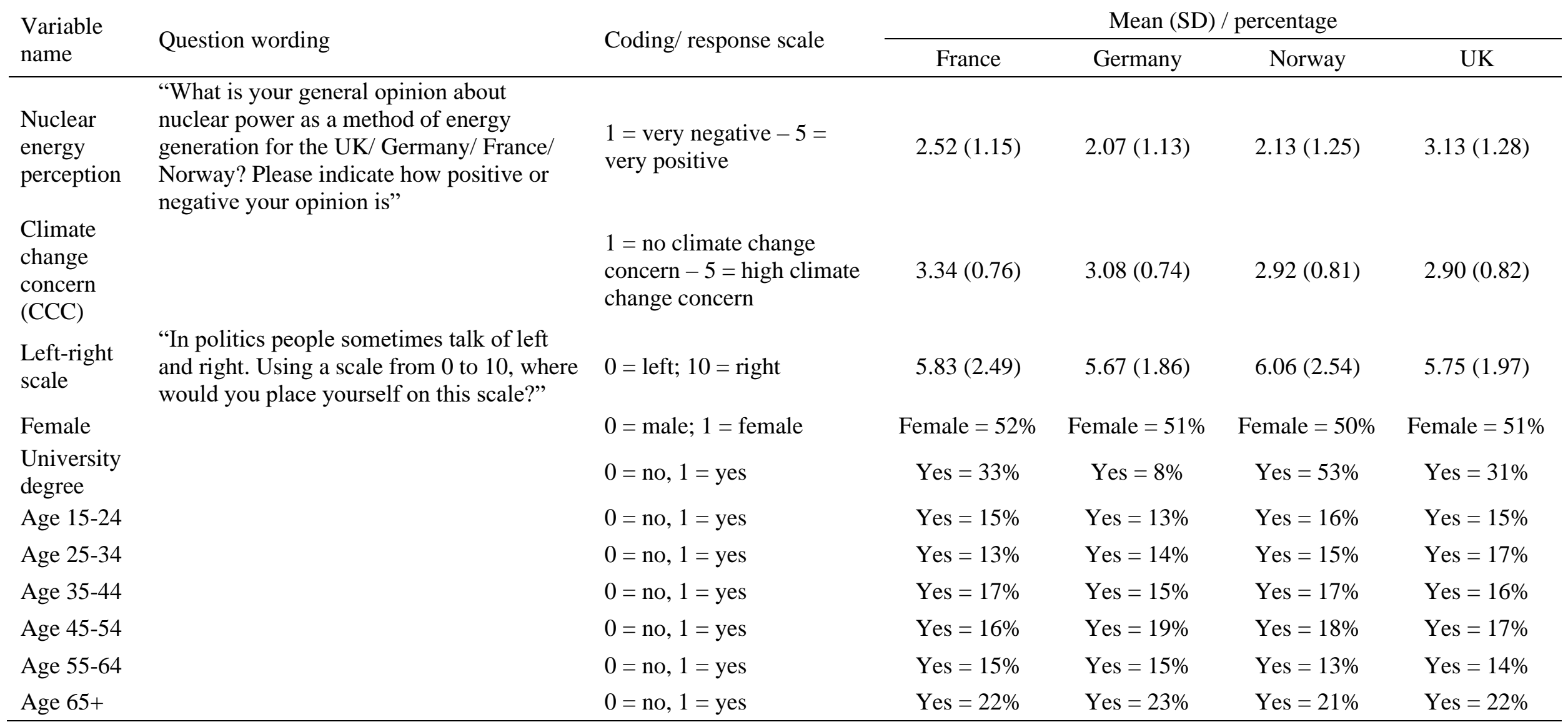




\section{Table 6}

Ordinal regression models predicting perceptions of nuclear energy from climate change concern and various control variables in the UK, France, Germany and Norway.

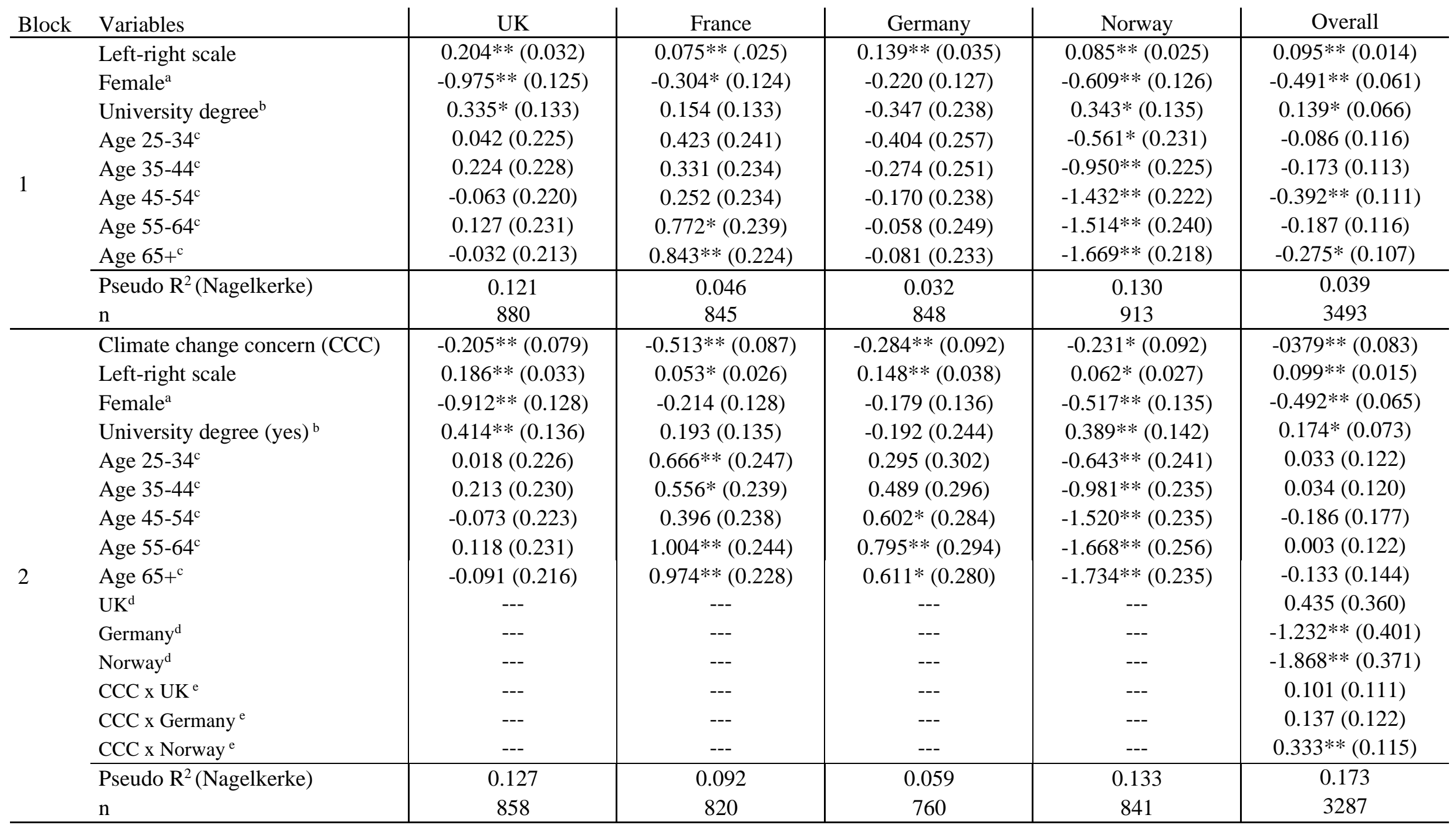

Note: Unstandardized coefficients reported with standard errors in parentheses; $* \mathrm{p}<0.05 ; * * \mathrm{p}<0.01 ;{ }^{\text {a }}$ Reference category: male; ${ }^{\mathrm{b}}$ Reference category: no university degree; ${ }^{\mathrm{c}}$ Reference category: age $15-24 ;{ }^{\mathrm{d}}$ reference category: France; ${ }^{\mathrm{e}}$ reference category: CCC x France; the left-right scale is a continuous variable with higher values corresponding to stronger right-wing orientation $(1=$ left; 11 = right $)$. 